\title{
WALTER BENJAMIN E AS METRÓPOLES MODERNAS: A NOÇÃO DE UMA EDUCAÇÃO ESTÉTICA EM INFÂNCIA BERLINENSE:1900 E DIÁRIO DE MOSCOU
}

Priscilla Stuart da Silva

\begin{abstract}
RESUMO
O presente artigo tem como objetivo discutir a noção de uma educação estética em Walter Benjamin. As fontes principais da investigação são constituídas pelos ensaios Infância berlinense: 1900 e Diário de Moscou, os quais, ao transcenderem os gêneros literários da "autobiografia" e dos "diários de viagem", conduzem-nos a reflexões que nos mostram o lugar da educação do corpo na constituição da subjetividade humana. Desse modo, através das metrópoles modernas Berlim e Moscou refletimos como as mesmas constituíram o autor como indivíduo e como pensador, na tensão entre as instâncias individual e coletiva na formação humana.
\end{abstract}

Palavras-chave: Educação Estética; Experiência; Educação dos Sentidos; Walter Benjamin.

\section{WALTER BENJAMIN AND MODERN METROPOLISES: THE NOTION OF A AESTHETIC EDUCATION IN BERLIN CHILDHOOD: 1900 AND DIARY OF MOSCOW}

\begin{abstract}
This article aimed to discuss the notion of an aesthetic education in Walter Benjamin. The main sources of research was constituted by essays Berliner Childhood around 1900 and Moscow Diary, which, to transcend the literary genres of the "autobiography" and "travel diaries", lead us to reflections that show us the place of education body in the constitution of human subjectivity. Thus, using modern metropolises Berlin and Moscow reflect how they were the author as an individual and as a thinker, in the tension between the individual and collective spheres in the human formation.
\end{abstract}

Keywords: Aesthetic Education; Experience; Education Body; Walter Benjamin. 


\section{O espaço da cidade na educação dos sentidos}

Duas coisas instruem o homem sobre toda a sua natureza: o instinto e a experiência.

Blaise Pascal

A cidade é o espaço moderno por excelência, lugar onde se encontram todas as tensões do espírito da modernidade, espaço de contradições, de guerras, da infância, do corte entre o domínio público e o privado, das expressões da linguagem que definiram o espaço individual do homem, do advento do romance; lugar, notavelmente, do apogeu de uma crise generalizada no ethos humano que nenhuma outra época suportou tanto como a moderna.

A cidade é a esfera e fundação do individualismo. $O$ espaço da modernidade fundou uma concepção humana a partir da noção de que "o homem moderno é, acima de tudo, um ser humano móvel", onde "o movimento autônomo diminui a experiência sensorial, despertada por lugares ou pessoas que neles se encontrem"2. O que surge é um afastamento radical da dimensão corporal em detrimento da racional. O corpo é negado, "o indivíduo moderno sofre uma espécie de crise táctil: deslocar-se ajuda a dessensibilizar o corpo" ${ }^{3}$. As grandes cidades são planejadas de acordo com o modo como o corpo humano é conhecido e esquadrinhado pela ciência.

Ao mesmo tempo em que o corpo ganha uma dimensão impessoal com a descoberta da anatomia, das funções respiratórias e circulatórias, a cidade é organizada e pensada de acordo com essas descobertas: ganha o mesmo caráter distante, formal. A urbanização das metrópoles movia-se na mesma ideia e ritmo de funcionamento do corpo:

Partindo da idéia de um corpo saudável, limpo e deslocando-se com total
liberdade, o desenho urbano previa uma cidade que funcionasse assim. [...]
Na concepção iluminista, a rua era um importante espaço urbano cruzando
áreas residenciais ou atravessando o centro da cidade.
Palavras como "artéria" e "veia" entraram para o vocabulário urbano no
século XVIII, aplicadas por projetistas que tornavam o sistema sanguíneo
como modelo para o tráfego. [...]
Construída logo após a Revolução Americana, Washington, DC, é um belo
exemplo desse tipo de planejamento urbano. O jogo de interesse entre os

1 SENNETT, Richard. Corpos em movimento. In: Aarão Reis. Rio de Janeiro: Record, 2003, p. 213.

Carne e pedra. Tradução de Marcos

2 SENNETT, 2003, p. 214.

3 SENNETT, 2003, p. 214.

Priscilla Stuart da Silva - Graduada em Filosofia pela UFSC, Mestre em Educação, também pela UFSC e Doutoranda em Educação (UFSC), Brasileira, residente em Florianópolis - SC, 
diversos poderes na jovem República impediu os urbanistas de aproveitar alguma cidade situada milhas ao norte, em parte já estabelecida, e forçouos a transformar uma área pantanosa, bem pouco hospitaleira, em uma capital nacional. O plano que eles adotaram resgata as crenças do lluminismo no poder de criar um ambiente saudável - onde o povo pode respirar livremente - por meio do desenho de uma cidade altamente organizada e compreensiva. ${ }^{4}$

Contudo, o século XVIII é também o período no qual a ideia da viagem como formativa e como fonte de inspiração poética emerge e se fortalece no espírito ocidental. Goethe ficara famoso com sua jornada italiana e reiterou o espírito da época, de que "movimento, viagem e exploração seriam capazes de ampliar a sensibilidade de qualquer um [...]". ${ }^{5}$ Diante disso, essa ode ao deslocamento do indivíduo moderno produziu ao mesmo tempo uma educação e formação pautadas por uma estética da existência, numa ênfase favorável ao corpo e aos sentidos que se movem. Parece haver, consequentemente, uma ambiguidade em relação ao corpo e suas possíveis potencialidades.

Benjamin é intensamente influenciado pelo romantismo alemão, particularmente por Goethe. Seus diários de viagem, a saber, sobre Ibiza, Moscou, Nápoles, Marselha, etc., são maneiras de desenvolver essa sensibilidade poética e estética, cultivada no lluminismo e ilustrada pela figura de Goethe na Alemanha do século XIX.

Benjamin, com sua tentativa de alcançar a iluminação profana ${ }^{6}$ (profane Erleuchtung) na cidade, na metrópole moderna - por vezes induzido pelo uso do haxixe $^{7}$ e do ópio - percebe e realiza os desejos do século XVIII, o antepassado

4 SENNETT, 2003, p. 220-222.

5 SENNETT, 2003, p. 228.

6 Segundo a apresentação feita ao livro Profanações, de Agamben, o ato de profanar, ou simplesmente profanação, teve origem no direito romano e "indicava o ato por meio do qual o que havia sido separado na esfera da religião e do sagrado voltava a ser restituído ao livre uso do homem". In: ASSMANN, 2007 apud AGAMBEN, 2007, p. 10.

7 Em Sobre o Haxixe e outras drogas, o berlinense descreve suas experiências com o uso dessas substâncias na cidade de Marselha. Em Imagens do pensamento encontra-se também uma versão simplificada dessa experiência. Vale a pena conferir um pequeno trecho da experiência alucinógena e da mudança na descrição na percepção da cidade: "Um dos primeiros sinais de que o haxixe começou a actuar é uma vaga sensação de premonição e angústia; qualquer coisa de estranho e inevitável se aproxima... [...]. Chegamos também a experiências próximas da inspiração, da iluminação... [...]. Agora fazem-se sentir as exigências de tempo e espaço que o fumador de haxixe experimenta. $\mathrm{E}$, como se sabe, são absolutamente régias, essas exigências. Para quem tomou haxixe, Versalhes ainda é pequeno, e a eternidade não Ihe basta. E no plano de fundo dessas dimensões imensas da vivência interior, da duração absoluta e do espaço incomensurável, instala-se agora um maravilhoso e sereno humor, tanto mais quanto maiores as contingências de espaço e tempo". In: BENJAMIN, 2004, p. 229-231.

Priscilla Stuart da Silva - Graduada em Filosofia pela UFSC, Mestre em Educação, também pela UFSC e Doutoranda em Educação (UFSC), Brasileira, residente em Florianópolis - SC, 
daquele no qual viveu o filósofo berlinense: conhecer a cidade pela dimensão dos sentidos ampliados, já que a cidade, em última instância, é um corpo também, um corpo urbano. Ampliar os sentidos pela experiência com entorpecentes dimensionaria os efeitos da cidade, suas perspectivas, aquilo que ela mostra, pois é na urbe o lugar que se realiza a formação humana na modernidade. A ideia de iluminação profana poderia, nesse contexto, ser interpretada como uma tentativa de reagir aos impactos, aos choques produzidos na/pela cidade ${ }^{8}$.

É importante destacar as novas direções que a sociedade ocidental tomou frente à Revolução Francesa e Russa. Entre outros aspectos - tanto positivos quanto negativos -, essas revoluções foram um marco da quebra com o passado e com a tradição. Fundara-se um novo calendário, novas perspectivas, o que permitiu maior liberdade de ação e movimento no espaço novo, espaço revolucionário. A ênfase sobre o corpo e suas potencialidades, entre elas a mobilidade, ressurge com força e vigor renovados ${ }^{9}$.

O corpo, no espaço da metrópole moderna, é sempre colocado à prova: nas guerras, nos festivais, nos protestos, no trabalho e, fundamentalmente, nas dificuldades. Ao mesmo tempo, é treinado também para agir e reagir e, à vista disso, a modernidade é um palco em que cada atitude humana é julgada a partir de regras e protocolos fundados no "contrato social" estabelecido para o funcionamento desse corpus urbano.

O período compreendido entre os anos 1848 e 1945 é chamado de "revolução urbana"10 , o mesmo período que se situam as experiências de Benjamin retratadas em Infância berlinense: 1900 e Diário de Moscou - retratos, respectivamente, de uma criança no interior de sua vida burguesa e de um viajante que caminha na contramão da urbanização em meio às maiores metrópoles ocidentais.

${ }^{8}$ Cf. 'La 'iluminación profana' [profane Erleuchtung] que conduce al espacio del cuerpo y de la imagen en el surrealismo puede ser comprendida así como la contrapartida a tales prácticas violentas de 'clarividencia' [Erhelhung] y, por lo tanto, ser interpretada una vez más como un concepto basado en el sentido de una reacción contra el impacto". In: WEIGEL, 1999, p. 66.

9 SENNETT, 2008, p. 244.

${ }^{10} \mathrm{Cf}$. "Durante a segunda metade do século XIX, todas as nações ocidentais foram varridas por transformações geoeconômicas. Em 1850, França, Alemanha e Estados Unidos também eram sociedades predominantemente rurais; um século mais tarde, a urbanização prevalecera, apresentando um alto índice de concentração populacional. Não é à toa que os cem anos transcorridos entre 1848 e 1945 são chamados de "revolução urbana". In: SENNETT, 2003, p. 261.

Priscilla Stuart da Silva - Graduada em Filosofia pela UFSC, Mestre em Educação, também pela UFSC e Doutoranda em Educação (UFSC), Brasileira, residente em Florianópolis - SC, 
Diário de Moscou é um relato de viagem que ultrapassa os limites do pessoal, do íntimo, da esfera privada. Com ele, ao reconstituir as contradições da capital russa, Benjamin salvou um gênero literário do seu caráter meramente recreativo. Ele expressa, em meio aos dramas humanos, um momento primordial da história, ao reconstruir na história individual humana a história coletiva. Ele quer contar a trajetória de uma cidade que fora palco de um dos mais importantes acontecimentos da breve história do século $X X^{11}$ : a revolução russa de 1917 e a formação de um povo pós-revolução. Mas Benjamin quer contar esta história por meio de uma experiência estética (sensorial) com a cidade, mostrando as ambiguidades da época. Para isso, reconstrói uma atmosfera entre 6 de dezembro de 1926 e o final de janeiro de $1927^{12}$ — momentos de consolidação do regime comunista russo, como pano de fundo da sua temática principal, a saber, novas formas de subjetividade na metrópole moderna, mesmo com todas as suas contradições, limiares, reticências, próprios desse período histórico. Moscou, nesse sentido, parece ser o lugar que melhor ilustra esse espírito social moderno.

Infância berlinense: $1900^{13}$ é outro ensaio de caráter pessoal que se alia ao Diário de Moscou e ao tema aqui proposto. Da ordem do particular, Infância é um texto que resgata a memória de um Benjamin adulto revisitando as lembranças da infância, no qual, de modo semelhante ao Diário, a cidade é apreendida por um corpo que descobre o mundo com os sentidos.

Os dois ensaios foram escritos quase que paralelamente e são, talvez, os textos de Benjamin com caráter mais pessoal, que revelam suas experiências na infância e na cidade de Moscou (período muito importante política e amorosamente para o berlinense, já que toda sua vida fora colocada em suspenso desde o momento em que viajou até a capital russa) ${ }^{14}$.

\footnotetext{
${ }^{11}$ Expressão usada em: HOBSBAWN, Eric. A era dos extremos: o breve século XX: 1914-1991. São Paulo: Companhia das Letras, 1995.

${ }^{12}$ SCHOLEN, Gershom. Prefácio. In: BENJAMIN, Walter. Diário de Moscou. São Paulo: Companhia das Letras, 1989.

${ }_{13}^{13}$ Utiliza-se a tradução realizada por João Barrento.

${ }^{14}$ Seu envolvimento com Asja Lacis e sua possível filiação ao partido comunista foram decisivos para a definição de ideias encontradas em obras posteriores, como as teses Sobre o conceito de história ou ainda o conjunto de ensaios de Imagens do pensamento. Asja Lacis "fora o principal motivo de sua ida a Moscou e estadia naquela cidade [...]. Esse texto, por sua vez, serviu não apenas para Benjamin tentar uma espécie de ersatz de suas desilusões amorosas - nessa sua estadia em Moscou ele acabou ficando muito mais tempo com o companheiro de Lacis, Bernhard Reich (1880-
}

Priscilla Stuart da Silva - Graduada em Filosofia pela UFSC, Mestre em Educação, também pela UFSC e Doutoranda em Educação (UFSC), Brasileira, residente em Florianópolis - SC, 
A cidade, notavelmente, é um tema recorrente em Benjamin. Como era um grande viajante, o autor escrevia sobre os lugares que visitava, como Marselha, Paris, Moscou, Nápoles, etc. Contudo, suas descrições não são as de um mero relator ou turista de viagem, posto que os escritos sobre a cidade são importantes na constituição do sujeito, já que existe uma tarefa pedagógica importante que Benjamin deixou como legado nessas obras. Essa tarefa parece caminhar em direção a uma concepção de educação estética, em que o corpo apreende aquilo que a cidade fornece como experiência (Erfahrung).

Importante se faz, antes de prosseguirmos, reconstruir brevemente o que Benjamin compreendia como Erfahrung e sua oposição ao conceito de vivência (Erlebnis), uma vez que são noções primordiais à compreensão e desenvolvimento de seu pensamento como um todo.

\title{
Breve percurso: experiência x vivência
}

\begin{abstract}
As experiências mais admiráveis, mais instrutivas, as experiências decisivas, são exatamente as experiências cotidianas, que estas constituem justamente o grande enigma que cada um tem sob seus olhos, mas que poucos compreendem como sendo um enigma, e que, para o pequeno número de verdadeiros filósofos, são justamente estes os problemas que permanecem ignorados, abandonados no meio do caminho e, por assim dizer, pisoteados pela multidão, antes que eles os recolham cuidadosamente e a partir desse momento resplandeçam como pedras preciosas do conhecimento.
\end{abstract}

Friedrich Nietzsche

A experiência (Erfahrung) é um dos conceitos centrais do pensamento de Walter Benjamin. A partir dele o autor discute sua teoria da história, da narração, os temas da infância, da linguagem, sua teoria pessimista do mundo por meio da discussão da melancolia moderna ${ }^{15}$, enfim, sua discussão sobre a cultura na modernidade. Tudo passa por este conceito, uma vez que toda a nossa maneira de ver o mundo foi reconfigurada desde o ponto em que rompemos um laço importante com a tradição que nos antecedeu, com a cultura como patrimônio, em suma, com nossa história. Perdemos o vínculo com o conto, com a narração, com o

1972), do que com a própria, que estava internada em um sanatório -, mas também a forma dos Diários serviu de laboratório para uma série de procedimentos metodológicos e de apresentação (Darstellung) que reencontraremos até o final de sua obra". In: SELIGMANN-SILVA, 2012, p. 167.

${ }^{15} \mathrm{Cf}$. A discussão sobre a melancolia moderna encontra-se na seguinte obra: BENJAMIN, Walter. Origem do drama trágico alemão. Tradução de João Barrento. Belo Horizonte: Autêntica, 2011, p. 143-166. 
aprendizado oral herdado de nossos antepassados, com a história material que nos precede. Estamos à mercê de uma eterna novidade: nossos atos estão fadados e são reféns de um eterno hoje, com um prazo de validade preso ao momento do próprio acontecimento.

O filósofo não iniciara sua investigação sobre a experiência moderna a partir da modernidade e da guerra de trincheiras ${ }^{16}$, ou então da pobreza de valores que hoje invalidam a sustentabilidade de uma cultura e de uma tradição. Sua preocupação estava vinculada, desde o início, às suas memórias de infância, especialmente a uma pequena frase dita por seu irmão mais jovem, por ele revelada numa carta endereçada a Adorno:

\begin{abstract}
El hecho de que las raíces de mi "teoría de la experiencia" se remontan a un recuerdo de infancia. Mis padres costumbraban llevarnos de paseo durante los meses de verano, y siempre los acompañábamos dos o tres de nosotros. Pero es en mi hermano en quien estoy pensando aquí. Luego de haber visitado uno $u$ otro de los lugares obligatorios en torno a Freudenstadt, Wegen o Schreiberhau, mi hermano solía acotar: 'Ahora podemos decir que hemos estado alli'. Esta observación quedó impresa de forma indeleble en mi mente. ${ }^{17}$
\end{abstract}

O trecho acima nos faz refletir sobre a crescente preocupação pessoal que o berlinense mantinha com a profusão de temas que trata em seus escritos: nota-se, portanto, uma necessidade de saber como adquirimos a experiência que acumulamos da/na vida, dos lugares pelos quais passamos e, fundamentalmente, das cidades nas quais vivemos. De alguma forma, tudo em Benjamin está vinculado à experiência formativa, a qual talvez pudéssemos chamar também de "afetiva", porque diz respeito a um momento pessoal, íntimo, circunstancial de seu passado com a família. Esse caráter subjetivo da experiência está presente, com bastante força, naquele pequeno extrato acima citado. O caleidoscópio de temas que se entrecruzam indica a necessária vinculação que um tema possui com o outro, como

\footnotetext{
${ }^{16}$ Cf. "Não, está claro que as ações estão em baixa, e isso numa geração que entre 1914 e 1918 viveu uma das mais terríveis experiências da história. [...] Porque nunca houve experiências mais radicalmente desmoralizadas que a experiência estratégica pela guerra de trincheiras, a experiência econômica pela inflação, a experiência do corpo pela fome, a experiência moral pelos governantes. Uma geração que ainda fora à escola num bonde puxado por cavalos viu-se abandonada, sem teto, numa paisagem diferente em tudo, exceto nas nuvens, e em cujo centro, num campo de forças de correntes e explosões destruidoras, estava o frágil e minúsculo corpo humano". In: BENJAMIN, 2010, p. 114-115.

${ }^{17}$ Citado por Martin Jay no livro Cantos de experiência (vide referências): "Benjamin a Adorno, 7 de mayo de 1940, em ob. Cit., pág. 326. El Hermano en cuestión era Georg Benjamin (1895-1942), quién se convirtió en comunista y murió en un campo de concentración nazi".
} 
a educação sensorial adquirida na cidade e seu vínculo político, por exemplo. Entendemos, contudo, a dificuldade crescente quando se escolhe um assunto, porque deixamos de lado outros da mesma magnitude, mas que, por uma falta de tempo para investigação, consideramos mais relevante falar somente de um, sabendo, contudo, que ocultamos outros vínculos necessários.

Por isso, a preocupação de Benjamin com a experiência está para além das discussões de caráter transcendental da história da filosofia, por exemplo, ou ainda da necessidade de achar um conceito necessário para compreender esse fenômeno. Benjamin parte da própria existência para pensar a realidade do conceito. Ele diagnostica a transformação social realizada na Europa após a 1a Guerra Mundial e observa as inúmeras modificações produzidas no interior de uma sociedade que provocaram mudanças não somente sociais, mas de cunho ideológico, comportamental e ético. Isso tudo está presente, de modo bastante particular, embora em íntima conexão, com as problemáticas que circunscrevem a obra de Benjamin, em textos como o Diário de Moscou e nas memórias de criança em Infância berlinense: 1900.

Diagnosticar a modernidade é, acima de tudo, analisá-la como uma época produtora de empobrecimento de experiências (Erfahrung) humanas comunicáveis. Benjamin nomeia a experiência empobrecida de vivência (Erlebnis). Talvez possamos considerar que "vivência" é um conceito cujo valor heurístico só se deixa entrever no contemporâneo, no presente, momento em que parece ganhar mais força explicativa do que quando o autor o formulou. Nosso afastamento é relativo à nossa própria inserção no movimento que o confirma. De qualquer modo, Martin Jay faz uma reflexão etimológica que nos ajuda a sistematizar esse conceito tão caro a Benjamin:

\footnotetext{
Erlebnis contiene la raíz de la palabra Leben (vida) y a veces se traduce como experiencia vivida. [...]. Aunque erleben es un verbo transitivo e indica la experiencia de algo, Erlebnis suele implicar una unidad primitiva, previa a cualquier diferenciación u objetivación. Normalmente localizada en el "mundo cotidiano" (el Lebeswelt) del lugar común y de las prácticas no teorizadas, puede sugerir asimismo, una intensa y vital ruptura en la trama de la rutina cotidiana. Pese a que Leben indica también la totalidad de una vida, Erlebnis generalmente connota una variante de la experiencia más inmediata, prerreflexiva y personal que Erfahrung. ${ }^{18}$
}

${ }^{18} \mathrm{JAY}, 2009$, p. 27.

Priscilla Stuart da Silva - Graduada em Filosofia pela UFSC, Mestre em Educação, também pela UFSC e Doutoranda em Educação (UFSC), Brasileira, residente em Florianópolis - SC, 
Em seu famoso ensaio "Experiência e pobreza", o berlinense vincula Erlebnis à barbárie, mais precisamente a dois tipos de barbárie: uma que impossibilita as experiências de serem transmitidas de uma geração à outra, condenadas a morrerem no elo entre as gerações; outra, uma nova barbárie, lugar em que emerge o novo e que não se vincula mais a uma tradição. Este último conceito parece ser alvo de uma nova reconfiguração na modernidade, pois nessa expressão recente de experiência surge um novo sujeito, o homem bárbaro ${ }^{19}$. Sua famosa frase presente nas teses sobre a história ${ }^{20}$ parece dar continuidade a esse pensamento, a saber, "nunca houve um monumento da cultura que não fosse também um monumento da barbárie" ${ }^{21}$. Benjamin parece aqui aludir a um tipo específico de experiência que diz respeito ao modo como experimentamos a história, a cultura, em última instância, a materialidade dos objetos. ${ }^{22}$

Esse bárbaro é capaz de constituir-se enquanto um sujeito de vivências individual e coletivamente - a partir de uma tábula rasa. Ele fundará uma cultura de vidro, que não deixa nada atrás de si. Poderíamos fazer uma comparação entre o sujeito arcaico e o sujeito contemporâneo. O próprio nome já revela o que os distingue fundamentalmente. Enquanto o sujeito arcaico prende-se à tradição, à história, à memória, ao seu passado, o homem contemporâneo está dissociado de todos os seus laços históricos porque não possui mais um vínculo direto com a memória coletiva. Ele vive o tempo do acontecimento. As coisas - seu valor - são mediadas pelo tempo do agora, do instante, não dizem respeito a um valor pretérito.

${ }^{19}$ Cf.: Para uma análise pós estruturalista sobre a questão da nova barbárie, ver: MATTÉl, JeanFrançois. A barbárie interior. Tradução de Isabel Maria Loureiro. São Paulo: UNESP, 2002. Neste livro, o autor analisa, desde os antigos até os dias de hoje, as formas com que a barbárie tomou forma na sociedade ocidental: "tanto no sentido próprio quanto no figurado, a destruição de um povo se manifesta sempre pela destruição de sua cultura, quer dizer, das obras que mostram, pela importância de origem, a fecundidade do homem. Delenda Cultura est: esse é o dobre moderno da barbárie que decompõe, desconstrói e destrói; numa palavra, arruína todas as colunas da civilização que elevam o homem acima de si mesmo. O barbáro, tal como viam Nietzsche, Simone Weil e Hannah Arendt, é o destruidor de colunas, aquele que a derruba no lodo ou a esvazia do interior, fazendo do mármore, areia e da areia, nada". (MATTÉl, 2002, p. 243).

${ }^{20}$ BENJAMIN, 2010.

${ }^{21}$ BENJAMIN, 2009, p. 225.

${ }^{22}$ Embora não temos condições de fazer uma análise pormenorizada de "Experiência e pobreza" e "Sobre o conceito de história", gostaríamos de indicar, contudo, que em ambos os textos Benjamin reflete sobre a maneira como os objetos de nossa realidade cultural definem o modo como nos relacionamos com ela, ou seja, refere-se a um tipo específico de experiência, entendida como resultado da mediação entre o sujeito e a cultura. 
Benjamin parece remeter a uma concepção de homem despersonalizada quando comenta a compreensão de "homem" contemporâneo de Paul Scheerbart:

\begin{abstract}
Scheerbart se interessa pela questão de como nossos telescópios, aviões e foguetes transformam os homens antigos em criaturas inteiramente novas, dignas de serem vistas e amadas. De resto, essas criaturas também falam uma língua inteiramente nova. Decisiva nessa linguagem é a dimensão arbitrária e construtiva, em contraste com a dimensão orgânica. É esse o aspecto inconfundível na linguagem dos homens de Scheerbart, ou melhor da sua "gente"; pois tal linguagem recusa qualquer semelhança com 0 humano, princípio fundamental do humanismo. ${ }^{23}$
\end{abstract}

Contudo, o caráter positivo que o alemão introduz no segundo conceito de barbárie parece ser devido à capacidade - que o filósofo percebe - do homem superar os aparatos técnicos pelo uso de sua imaginação. Mesmo depois de uma longa jornada de trabalho, o homem ainda consegue sonhar, realizar seus desejos por meio da arte, por exemplo ${ }^{24}$. Essa nova constituição da experiência parece se realizar através da imagem da criança, que sonha e imita os objetos da vida real porque sua imaginação possibilita tal jornada. De modo semelhante, o viajante que se deixa perder numa cidade ${ }^{25}$ e observa os traços fisionômicos do lugar realiza também uma experiência autêntica.

Poderíamos ainda especular que a concepção despersonalizada do homem na história, esse conceito "novo e positivo de barbárie", faz surgir um novo indivíduo semelhante ao "além-homem" de Nietzsche que, diante da morte de todas as concepções de mundo e de valores - época niilista -, não se identifica mais com o seu passado, um homem pós-humano, em que os valores são ultrapassados para dar margem a uma ideia de superação.

Essa concepção nova de homem talvez possa se aproximar dos primeiros escritos de Benjamin sobre o conceito de experiência, já que ele possuía uma forte necessidade de denunciar o preconceito contra o espírito juvenil, seu potencial e força revolucionários. Integrante de movimentos juvenis ${ }^{26}$, sua linguagem é a de um

\footnotetext{
${ }^{23}$ BENJAMIN, 1993, p. 117.

${ }_{24}^{24}$ PEREIRA, 2012, p. 51.

${ }^{25}$ Cf. "Não há nada de especial em não nos orientarmos numa cidade. Mas perdermo-nos numa cidade, como nos perdermos numa floresta, é coisa que precisa de se aprender." (BENJAMIN, 2004, p. 82).

${ }^{26}$ Cf. "Benjamim estava nesta época totalmente voltado para a organização do movimento de juventude, Berliner freie Studentschaft, da qual foi presidente em 1914. Os escritos do período respondem às questões vividas no movimento ou, mais exatamente, elaboram-nas teoricamente,
}

Priscilla Stuart da Silva - Graduada em Filosofia pela UFSC, Mestre em Educação, também pela UFSC e Doutoranda em Educação (UFSC), Brasileira, residente em Florianópolis - SC, 
combatente - "travamos nossa luta por responsabilidade" - que valoriza as palavras de ordem e ação contra os clichês do discurso do adulto "experiente". Nesse período, Benjamin ainda não havia abordado a distinção entre experiência (Erfahrung) e vivência (Erlebnis), que se constituiria mais tarde em sua obra, ou sua crítica ao conceito de Kant: um conceito de experiência a partir de uma filosofia do futuro 27 .

Muricy $^{28}$ acredita que a concepção de experiência de Benjamin em 1913 estava mais relacionada à sua noção de Erlebnis desenvolvida posteriormente, experiência entendida como contraposta ao que é novo, estritamente vinculada ao imediatismo dos acontecimentos, sem novidade, pura repetição.

Poderíamos inferir que, antes de qualquer relação com a vivência empobrecida pelas ruínas que restaram das guerras, a experiência, neste ensaio da juventude, faz uma crítica vivaz à estagnação das tradições, dos povos e ao abismo que se abriu entre uma geração e sua sucessora, devido à sua falta de diálogo e comunicação ${ }^{29}$. Refere-se, portanto, à grande dificuldade e barreira estabelecida no espírito humano: a conciliação entre a tradição e o que está nascendo, a novidade, o futuro.

No ensaio "O narrador - considerações sobre a obra de Nikolai Leskov" 30 , a perda da experiência na modernidade está diretamente ligada ao desaparecimento da figura do narrador, do contador de histórias, daquelas lições de vida exemplares que constituíam a tradição das famílias, das aldeias, em suma, de uma comunidade. Por isso, juntamente com o surgimento dessa nova estrutura de homem, que não é mais constituído ou formado a partir de ideais milenares de uma sociedade, surge

procurando situá-las em um contexto estritamente filosófico. Foram, na sua maioria, publicados na Der Anfang [O Princípio], a revista do movimento e assinadas com o sugestivo pseudônimo de Ardor. O movimento de juventude (Jugendbewegung), ao qual se liga Benjamin, opunha-se às tradicionais e conservadoras corporações estudantis das universidades alemãs. A ambição era grande: propunha-se à transformação radical da sociedade e da cultura pela ação de uma juventude esclarecida. Uma reforma pedagógica ampla, uma mudança de mentalidade dos jovens, era vista como decisiva para o renascimento da cultura alemã." (MURICY, 2009, p. 37).

${ }^{27}$ Cf. Benjamim discutirá a distinção entre Erfahrung e Erlebnis essencialmente nos ensaios "Experiência e pobreza" e "O narrador - considerações acerca da obra de Nicolai Leskov". Sobre a crítica do conceito de experiência em Kant ver o ensaio: "Sobre o programa de uma filosofia do futuro".

${ }^{28}$ Cf. MURICY, 2009, p. 44.

${ }^{29}$ Cf. Akira Kurosawa, cineasta japonês, ilustra o problema da incomunicabilidade nas tradições das famílias num filme chamado Rapsódia de Agosto, de 2002.

${ }^{30}$ BENJAMIN, Walter. O narrador - considerações sobre a obra de Nikolai Leskov. In: Obras Escolhidas. São Paulo: Brasiliense, 2009. 
também uma nova forma de narrativa: a narração das ruínas. E o palco das ruínas é a metrópole moderna, que transforma a maneira pela qual apreendemos, pelos sentidos, a experiência, conforme veremos a seguir.

\title{
A experiência sensorial na cidade
}

\begin{abstract}
Com o passar do tempo, nas narrativas de Marco, as palavras foram substituindo os objetos e os gestos: no início, exclamações, nomes isolados, verbos secos; depois, torneios de palavras, discursos ramificados e frondosos, metáforas e imagens. O estrangeiro aprendera a falar a língua do imperador, ou o imperador a entender a língua do estrangeiro. Mas dirse-ia que a comunicação entre eles era menos feliz do que no passado: claro que as palavras serviam melhor do que os objetos e os gestos para apontar as coisas mais importantes de cada província ou cidade monumentos, mercados, trajes, fauna e flora - todavia, quando Polo começava a dizer como devia ser a vida naqueles lugares, dia após dia, noite após noite, as palavras escasseavam, e pouco a pouco voltava a fazer uso de gestos, caretas, olhares.
\end{abstract}

Italo Calvino

A modernidade produz um novo sujeito e uma concepção inédita de experiência, a qual se reconfigura na cidade, mais precisamente nas metrópoles modernas: Paris, Berlim, Londres, Moscou, Nápoles, etc. A cidade é o lugar onde se expressa uma forma recente de definir o sujeito moderno.

O "novo homem" identifica-se com as ruas porque nela encontra um âmbito, uma instância impessoal, um fora de si. As experiências de hoje, como afirma Agamben, não são mais realizadas no próprio sujeito, mas fora dele ${ }^{31}$. Benjamin "previra" uma nova noção de experiência para o indivíduo contemporâneo, um "sair das cinzas" da barbárie. Qual seria essa promessa para um futuro vindouro? Agamben parece partir da concepção benjaminiana de um futuro que essa barbárie positiva pode trazer. Para ele, o homem necessita preparar esse novo lugar de experiências:

\footnotetext{
Posta diante das maiores maravilhas da terra (digamos, o pátio de los leones, no Alhambra), a esmagadora maioria da humanidade recusa-se hoje a experimentá-las: prefere que seja a máquina fotográfica a ter experiência delas. Não se trata aqui, naturalmente, de deplorar esta realidade, mas de constatá-la. Pois talvez se esconda, no fundo desta recusa aparentemente disparatada, um grão de sabedoria no qual podemos adivinhar, em hibernação, o germe de uma experiência futura. A tarefa que este escrito se propõe - retomando a herança do programa benjaminiano
}

\footnotetext{
${ }^{31}$ AGAMBEN, 2008, p. 23.
}

Priscilla Stuart da Silva - Graduada em Filosofia pela UFSC, Mestre em Educação, também pela UFSC e Doutoranda em Educação (UFSC), Brasileira, residente em Florianópolis - SC, 
$<<$ da filosofia que vem $>>$ - é a de preparar o lugar lógico em que este germe possa atingir a maturação. ${ }^{32}$

O novo conceito de experiência e o conceito positivo de barbárie surgem, nesse caso, como vivência (Erlebnis) rompida com qualquer vínculo com a tradição. O novo homem é destituído de passado, ele não olha para frente com o peso dos erros daqueles que o antecederam. Ele caminha com leveza, suas ações só dizem respeito ao agora, ao acontecimento, caminhando com um olhar, uma audição, um tatear, um degustar e um cheirar novos, não determinados pelo hábito, pelo protocolo, pelas regras, pelo engessamento histórico. Esse sujeito parte para a descoberta do mundo com seu próprio corpo, liberto para a novidade, pelo espaço e tempo novos, seus sentidos estão ampliados. Torna-se tão pleno que se sente mais apto para a ação revolucionária:

O contemporâneo que, ao ler uma obra de história, reconhece com que longa mão a miséria que Ihe sobrecaiu vem sendo preparada - e mostrar isto ao leitor deve ser uma tarefa que se acerca do coração do historiador adquire, por isso, uma alta opinião de seus poderes. Uma história que ensina o povo desse modo não os faz melancólicos, mas the proporciona armas. $^{33}$

Essa concepção de ação revolucionária na história nos remete às categorias de espaço e tempo que suscitam e remetem à teoria benjaminiana da história aberta e da imagem dialética, intimamente ligadas à sua concepção de experiência. A história aberta representa um "ajuste de contas" que as novas gerações realizam com o passado, com a linhagem que os antecederam. O tempo histórico - sob essa crescente perspectiva - promove um conceito de tempo não cronológico, continuum, mas um tempo em que passado e presente estejam unidos e conduzidos a fazer do futuro um espaço, lugar em que não haja catástrofes, opressão das classes oprimidas, mas uma realidade em que predomine uma história de construção ${ }^{34}$.

Nesse sentido, as categorias de espaço e tempo representam, no nosso entendimento, o solo germinativo dessa nova barbárie, ao mesmo tempo em que parece estar relacionada ao movimento que os sentidos e o corpo como um todo

\footnotetext{
${ }^{32}$ AGAMBEN, 2008, p. 23.

${ }^{33}$ BUCK-MORSS, 2002, p. 343.

${ }^{34}$ Cf. BENJAMIN, Walter. Sobre o conceito de história. In: Sergio Paulo Rouanet. São Paulo: Brasiliense, 2010.
} Obras escolhidas. Tradução de 
realizam nessa concepção inédita de experiência, e que possam promover um verdadeiro acerto de contas com a história. Sigrid Weigel defende que a noção de corpo e de corporalidade em Benjamin aparece em sua obra como imagem. Vejamos:

\begin{abstract}
El cuerpo no se encuentra fuera de la historia, ni tampoco se lo entiende como perteneciente a la naturaleza en oposición a la Cultura. También el cuerpo tiene una historia. El cuerpo es, al mismo tiempo, la matriz y el lugar de ajustes de cuentas de la historia./Benjamin había destacado de modo particularmente significativo la importancia de la historia para la materialidad y corporeidad (lo que es ahora un bastión tan relevante en la teoría actual), aun cuando esto no haya despertado la debida atención./ [...] en su obra siempre se da un entrelazamiento de cuerpo e historia, ello sucede en el área de un espacio de la imagen, de tal modo que el cuerpo, en tanto matriz de la historia, aparece siempre estructurado como imagen. ${ }^{35}$
\end{abstract}

Ainda sobre a experiência moderna, podemos lê-la em vários escritos de Benjamin, principalmente em alguns aforismos do Livro das Passagens: em figuras alegóricas como o flâneur, a criança, o trapeiro, a prostituta, o colecionador, e tantas outras: alegorias que representam o caráter de limiar da cidade, a conciliação entre o antigo e o moderno, o público e o privado. São figuras que representam a contradição e o espírito da modernidade, permitindo uma maneira de compreender esse novo sujeito e seu espaço par excellence, a cidade. Esse mundo repleto de figuras alegóricas "permite a Benjamin tornar a experiência de um mundo em fragmentos visivelmente palpável”36, mas, ao mesmo tempo, elas não estão bem estabelecidas, já que se situam à margem da cidade, sem um papel delimitado. Assim, figuram tanto entre o estar presente e o não adaptado, e cujos papéis sociais ainda não se encontram completamente traçados, pois são a expressão de um momento histórico em que o rompimento com o passado não significa a agregação de certos elementos (desse passado) no novo presente.

De qualquer forma, merece destaque o fato do conceito de experiência benjaminiano estar - notavelmente - pautado pelas impressões suscitadas pelo corpo, que se abre para o mundo. Em Imagens do pensamento, no aforismo "Ler romances", Benjamin argumenta que "sem dúvida existe um alimento cru da experiência - exatamente como existe um alimento cru do estômago — , ou seja,

\footnotetext{
${ }^{35}$ WEIGEL, 1999, p. 88-89.

${ }^{36}$ BUCK-MORSS, 2002, p. 41.
}

Priscilla Stuart da Silva - Graduada em Filosofia pela UFSC, Mestre em Educação, também pela UFSC e Doutoranda em Educação (UFSC), Brasileira, residente em Florianópolis - SC, 
experiências no próprio corpo"37. A aquisição de experiências é uma alusão direta aos sentidos do corpo aberto ao mundo.

As figuras que Benjamin propõe como chaves de leitura desse novo tempo, a exemplo do trapeiro, do colecionador, da criança e da prostituta, são, como já dito, ambíguas, e fundam uma nova sensibilidade histórica: a experiências das ruas ${ }^{38}$. E entre esses "personagens" emblemáticos, que são parte da narrativa da metrópole urbana, destaca-se, por exemplo, o flâneur, que "no asfalto sobre o qual caminha, seus passos despertam uma surpreendente ressonância [audição]. A iluminação a gás que recai sobre o calçamento lança uma luz ambígua sobre este duplo chão [visão]" ${ }^{39}$. Benjamin pensa a cidade como a extensão da casa e quiçá também da existência. As ruas são parte de um habitat familiar para o flâneur, lugar onde ele se constitui, absorve os elementos que the formam como poeta: a poeira das ruas, as vitrines, os espectros produzidos pelo reflexo dos vidros, o cheiro sintético da vida urbana, o barulho dos transeuntes, dos automóveis... "a rua como intérieur". 40

A rua é também intérieur porque é o lugar em que mora o coletivo, a massa, as pessoas em conjunto. Elas se identificam e se formam nessa paisagem: a dos corredores, das ruas, das empresas, dos automóveis, das praças, do asfalto. Esses são lugares que ecoam, reverberam a condição de vida das cidades e de seus moradores. Contudo, é na experiência do flâneur que a existência se abre e produz perspectivas e possibilidades. A leitura da cidade é dada por este personagem peculiar. O próprio flâneur é um personagem móvel, ele se transforma,

\footnotetext{
${ }^{37}$ BENJAMIN, 2009, p. 275.

${ }^{38}$ Cf. João do Rio compartilha com Benjamin a mesma experiência na Alma encantadora das ruas: "A rua nasce, como o homem, do soluço, do espasmo. Há suor humano na argamassa do seu calçamento. Cada casa que se ergue é feita do esforço exaustivo de muitos seres, e haveis de ter visto pedreiros e canteiros, ao erguer as pedras para as frontarias, cantarem, cobertos de suor, uma melopéia tão triste que pelo ar parece um arquejante soluço. A rua sente nos nervos essa miséria da criação, e por isso é a mais igualitária, a mais socialista, a mais niveladora das obras humanas. [...] A rua é a eterna imagem da ingenuidade. Comete crimes, desvaria à noite, treme com a febre dos delírios, para ela como para as crianças a aurora é sempre formosa, para ela não há o despertar triste, quando o sol desponta e ela abre os olhos esquecida das próprias ações, é, no encanto da vida renovada, no chilrear do passaredo, no embalo nostálgico dos pregões - tão modesta, tão lavada, tão risonha, que parece papaguear com o céu e com os anjos... [...] Essas qualidades nós as conhecemos vagamente. Para compreender a psicologia da rua, não basta gozar-lhe as delícias como se goza o calor do sol e o lirismo do luar. É preciso ter espírito vagabundo, cheio de curiosidades malsãs e os nervos com um perpétuo desejo incompreensível, é preciso ser aquele que chamamos flâneur e praticar o mais interessante dos esportes - a arte da flanar. É fatigante o exercício?" In: RIO, 2007, p. 2.

${ }^{39}$ BENJAMIN, 2009, p. 462.

${ }^{40}$ BENJAMIN, 2009, p. 466.
}

Priscilla Stuart da Silva - Graduada em Filosofia pela UFSC, Mestre em Educação, também pela UFSC e Doutoranda em Educação (UFSC), Brasileira, residente em Florianópolis - SC, 
metamorfoseia-se, podendo se converter em todos os demais personagens: criança, jogador, detetive, etc. Ele condensa todas as figuras em uma só, já que "o flâneur é usado por Benjamin para a missão de reconhecimento do labirinto da modernidade", [...] a presença do flâneur [funciona] como instrumento de orientação e mapeamento da sociedade" nas metrópoles modernas ${ }^{41}$. Segundo Bolle, podemos identificar um verdadeiro mapa sociológico por meio da figura do flâneur. a "aristocracia, [a] burguesia, [as] classes trabalhadoras, [os] produtores de 'cultura' e os 'desclassificados"'42. Ele encerra em si os conflitos, contradições, perspectivas e possibilidades desse tempo histórico tão peculiar. Ele representa as ambiguidades e o território, o espaço de passagem, limiar desse novo ambiente urbano, no qual "expressa-se a ambivalência dessa 'figura do limiar' que é o flâneur: com um pé ele ainda faz parte da sociedade, com outro já está fora dela" ${ }^{43}$.

Essas figuras alegóricas, todas com seu caráter marginalizado, que podem ser - todas elas - representadas pelo flâneur, mostram um emblema social muito impactante da cidade moderna:

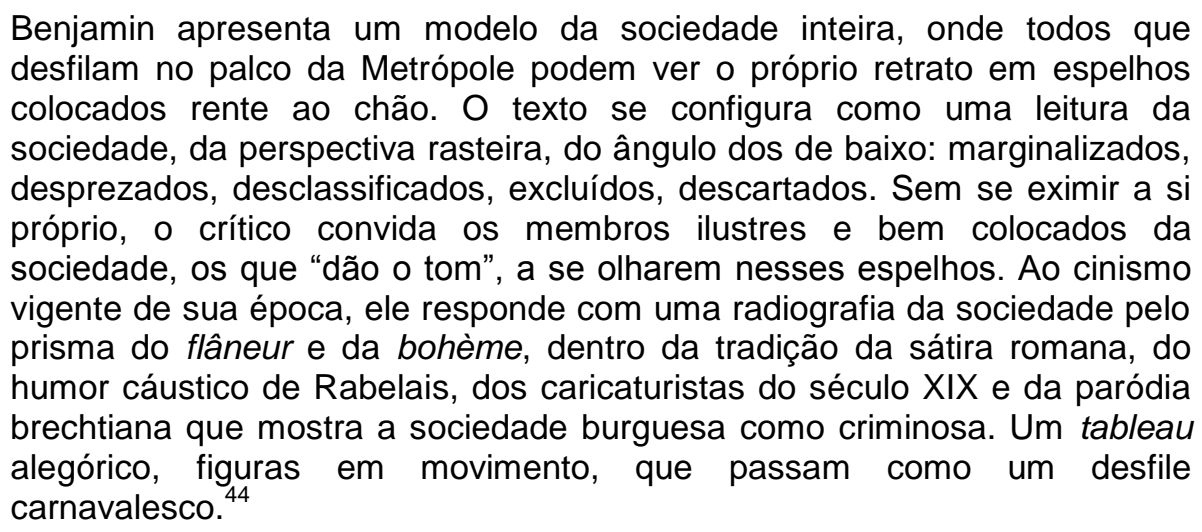

Para o autor berlinense, a leitura da modernidade só poderia ser feita a partir das classes baixas, da representação de uma sociedade não estigmatizada por uma classe sempre favorecida pelos padrões sociais. A mudança social de uma época é vista pelos impactos e desdobramentos sentidos pelos marginalizados, pela "periferia". Para isso, Benjamin escolheu Berlim e Moscou. Segundo Bolle:

\footnotetext{
${ }^{41}$ BOLLE, 2000, p. 372.

42 BOLLE, 2000, p. 372.

43 BOLLE, 2000, p. 393.

${ }^{44}$ BOLLE, 2000, p. 396.
}

Priscilla Stuart da Silva - Graduada em Filosofia pela UFSC, Mestre em Educação, também pela UFSC e Doutoranda em Educação (UFSC), Brasileira, residente em Florianópolis - SC, 
Em última instância, a Metrópole moderna é mostrada, na obra de Benjamin, a partir da ótica dos marginalizados e desclassificados, dos que vivem na periferia. Essa representação tem sua base histórica na época da Revolução Industrial, nas metrópoles de Paris e Londres; numa fase posterior, também em Berlim e Moscou, e, marginalmente, Nápoles. Na "capital do século XIX", o crítico focaliza as multidões pauperizadas, na era da consolidação do capitalismo. Estendendo-se até o limiar da época do Imperialismo, o estudo benjaminiano do século XIX sugere uma ampliação do campo de vista, uma superação da perspectiva exclusivamente europeia. ${ }^{45}$

Certamente, Berlim e Moscou não são capitais repletas de marginalizados, embora a ótica de Benjamin seja a da classe dos oprimidos, no intuito de ressaltar as diferenças sociais existentes nessas capitais e os "personagens" históricos que não encontram espaço na nova ordem social vigente. Sua abordagem visa revelar as ambiguidades e discrepâncias que se encontram no interior de uma sociedade taxada de "moderna".

A própria figura do narrador tradicional é retomada nessa nova configuração da sensibilidade: ele pode ser visto como o trapeiro, aquele que não deixa rastros na história, que não possibilita um depois para a memória, algo a ser narrado, mas cujo olhar, em contrapartida, não deixa de reconhecer os "cacos da história". Gagnebin define pontualmente os traços desse "novo narrador":

O narrador também seria a figura do trapeiro, do Lumpensammler ou do chiffonnier, do catador de sucata e de lixo, esta personagem das grandes cidades modernas que recolhe os cacos, os restos, os detritos, movidos pela pobreza, certamente, mas também pelo desejo de não deixar nada se perder. $^{46}$

O empobrecimento da experiência produz ainda outras duas quebras com a tradição, entre 0 velho e o novo: a separação entre 0 ato de narrar e 0 objeto histórico. A perda da experiência de narrar impossibilita o reconhecimento dos objetos e obras de arte historicamente definidos como tais, visto que já não estão mais vinculados ao passado. O objeto é destituído de valor e o que sobra é peso e ruína. Não é mais possível a acumulação da cultura, logo, não há uma legenda, uma história que a vincule ao objeto ${ }^{47}$.

\footnotetext{
${ }^{45}$ BOLLE, 2000, p. 397.

${ }^{46}$ GAGNEBIN, 2009, p. 54.

${ }^{47}$ AGAMBEN, 2012, p. 174.
}

Priscilla Stuart da Silva - Graduada em Filosofia pela UFSC, Mestre em Educação, também pela UFSC e Doutoranda em Educação (UFSC), Brasileira, residente em Florianópolis - SC, 
Por isso, a obra de arte do poeta da cidade, ou o flâneur, é a poeira das ruas, matéria de inspiração, imaginação, não mais monumento histórico. No caso de Benjamin, o próprio texto, isto é, a materialidade da escrita, tornou-se patrimônio e testemunho da história.

Certamente, a produção de uma sensibilidade nova historicamente tem suas vicissitudes, como, aliás, tudo que diz respeito à modernidade e às reflexões de Walter Benjamin sobre esse tempo ${ }^{48}$. Esta sensibilidade também é educada para responder a uma necessidade desse novo tempo: a uma possível falta de sentido histórico nas ações humanas.

\title{
A educação dos sentidos em Berlim e Moscou
}

\begin{abstract}
O que torna incomparável e irrepetível a primeira visão de uma aldeia, de uma cidade no meio da paisagem, é o fato de nela o que está longe vibrar numa estreita ligação com o que está próximo. Ainda não se fizeram sentir os efeitos do hábito. Mal começamos a orientar-nos, logo a paisagem desaparece como a fachada de uma casa quando entramos nela. Ainda não ganhou preponderância através de constante exploração, transformada em hábito. Assim que começamos a orientar-nos no lugar, nunca mais aquela primeira imagem poderá ser reconstituída.
\end{abstract}

Walter Benjamin

Nossa análise sobre a relação entre subjetividade e cidade considera esse movimento muito presente nos textos analisados, Infância berlinense: 1900 e Diário de Moscou, que vai da esfera privada, da dimensão pessoal, para o espaço público, e que é o território par excellence no qual se dá a formação (Bildung), a saber, a cidade. Adorno, por exemplo, já havia identificado isso quando fez a oposição entre urbanidade e campo ${ }^{49}$.

Benjamin também percebera os limiares entre a cidade e o campo, como expressa em Diário de Moscou. Na Moscou recém-urbanizada da época, os elementos provincianos ainda se fazem presentes com bastante força, como em

\footnotetext{
${ }^{48}$ Como exemplo, poderíamos citar sua discussão sobre o cinema em "A obra de arte na época de sua reprodutibilidade técnica", em que Benjamin comenta sobre o ambíguo sentido que o cinema nova forma de arte - é dotado: por um lado, a perda da aura e a massificação da arte dadas pela capacidade de reprodução técnica e, por outro, o aumento de sua dimensão social e política.

${ }^{49} \mathrm{Cf}$. "A formação cultural (Bildung) precisa corresponder à urbanidade, e o lugar geométrico da mesma é a linguagem. Ninguém pode ser recriminado por ser do campo, mas ninguém deveria também transformar este fato em um mérito, insistindo em permanecer assim. Quem não conseguiu emancipar-se da província, posiciona-se de um modo extra-territorial em relação à formação cultural". In: ADORNO, Theodor. A filosofia e os professores. In: emancipação. Tradução de Wolgang Leo Maar. São Paulo: Paz e Terra, 2010, p. 64-71.
} 
outras metrópoles, cenários ainda comuns na construção da paisagem moderna. Benjamin ressalta o limiar entre a cidade e o campo a propósito dos trapeiros, ao concluir que estes eram os únicos que se aventuravam a fazer barulho em Moscou, a mais silenciosa das grandes cidades que Benjamin conhecera:

\begin{abstract}
Só uma casta desfila ruidosamente pelas ruas: os trapeiros com seus sacos nas costas; seus chamados melancólicos atravessam todas as ruas de Moscou, uma ou mais vezes por semana. Há algo de singular nestas ruas: nelas, a aldeia russa brinca de esconde-esconde. Entrando por um dos grandes portões - frequentemente fechados com grades de ferro forjado, mas nunca encontrei qualquer delas trancada - a pessoa se vê no limiar de uma ampla área residencial que muitas vezes se esparrama de forma tão extensa e generosa que é como se o espaço nesta cidade nada custasse. Uma quinta rural ou uma aldeia estendem-se assim à sua frente. O chão é acidentado, crianças andam de trenó, removem a neve com pás; barracões para madeira, ferramentas ou carvão pelos cantos, árvores aqui e acolá, escadas primitivas de madeira ou anexos dão às laterais ou aos fundos das casas, cujas fachadas apresentam um aspecto bastante urbano, um ar de casas camponesas russas. Assim, a rua adquire a dimensão de paisagem. - De fato, em lugar algum Moscou tem realmente a aparência da cidade que é; ela mais parece o subúrbio de si mesma. ${ }^{50}$
\end{abstract}

A propósito da temática de Diário de Moscou, o texto constitui-se de um relato de viagem que expressa o cotidiano de Benjamin na capital russa em companhia de Asja Lacis e Bernard Reich ${ }^{51}$. Benjamin viajara para Moscou por um motivo passional: seu romance com Asja - mulher notável que o inspirou na produção de Rua de sentido único ${ }^{52}$ - e por seu envolvimento com o comunismo ${ }^{53}$. Suas

${ }^{50}$ BENJAMIN, 1989, p. 83.

${ }^{51}$ Segundo nota do tradutor do Diário, Reich fora diretor (entre outras funções) de teatro e escreveu junto com Benjamin o ensaio "Revue oder Theater". Asja teve um romance com Reich e também era ligada ao teatro comunista russo. "Lacis via o seu trabalho como parte integral da transformação revolucionária de uma sociedade. Como agente inovadora de um teatro para crianças proletárias, ela desenhou uma pedagogia infantil revolucionária que era a antítese de uma doutrina autoritária". In: BUCK-MORSS, 2002, p. 37.

${ }^{52}$ Benjamin dedica esse conjunto de aforismo a Lacis: "Esta rua chama-se Rua Asja Lacis em homenagem àquela que como um engenheiro a abriu no corpo do autor deste livro". In: BENJAMIN, 2004 , p. 7.

${ }^{53}$ Cf. "Só fatores exclusivamente externos impedem-me de entrar no Partido Comunista Alemão. Agora seria o momento indicado, e talvez seja perigoso deixá-lo passar. Justamente pelo fato de filiação ao Partido ser para mim, possivelmente apenas um episódio, não é aconselhável adiá-la ainda mais. Mas há, e permanecem, os fatores externos, sob a pressão dos quais eu me pergunto se não seria possível, através de trabalho intensivo, consolidar concreta e economicamente uma posição independente na esquerda que continuasse me assegurando a possibilidade de uma produção abrangente dentro de minha atual esfera de trabalho. Mas a questão é, justamente, se essa produção pode ser levada adiante, a uma nova fase, sem que haja uma ruptura. [...] Outra consideração: filiar-se ao Partido? Vantagens decisivas: uma posição sólida, um mandato, ainda que apenas virtual. Contato organizado com as pessoas. Por outro lado: ser comunista em um Estado onde governa o proletariado significa renunciar completamente à independência individual. Delega-se assim ao Partido a tarefa de organizar a própria vida. [...] Dentro do Partido: a enorme

Priscilla Stuart da Silva - Graduada em Filosofia pela UFSC, Mestre em Educação, também pela UFSC e Doutoranda em Educação (UFSC), Brasileira, residente em Florianópolis - SC,

E-mail: priscillastuart.di@gmail.com 
descrições sobre a fisionomia da cidade russa e a educação proletária mostram seu grande interesse em investigar o que o regime comunista tinha de controverso e no que se aproximava de uma sociedade burguesa. Moscou é relatada, grosso modo, como uma cidade repleta de contradições, de ambiguidades, uma característica que a aproxima de outras grandes metrópoles da época, mas talvez com uma peculiaridade muito própria: nela, as dubiedades ainda estão bastante visíveis. Benjamin observa, ademais, pela moda, as discrepâncias dessa urbe:

[...] Elegância urbana e trajes camponeses misturam-se nos homens e mulheres. Aqui e acolá, como também em outras grandes cidades, encontram-se ainda (entre as mulheres) o traje típico camponês. ${ }^{54}$

Outro aspecto que incita as reflexões de Bolle sobre essa obra de Benjamin diz respeito às aspirações do Diário de Moscou, da busca do filósofo alemão por uma compreensão de si mesmo tanto em Moscou quanto na sua cidade natal:

Toda a problemática da estada de Benjamin em Moscou se condensa nessa passagem; as emoções pessoais se cruzam com as linhas de força da vida política e intelectual. Por um momento se dissipa a neblina das sempre frustradas expectativas eróticas e emocionais em relação a Asja, e de sua surda rivalidade com Reich, e ele enxerga as bases materiais e psicossociais de uma vida de intelectual em Moscou. A figura de Reich é para Benjamin também um meio para se perceber a si mesmo. Em comparação com ele - muito bem relacionado em Moscou, membro da classe dominante - Benjamin se dá conta de sua própria existência: a de um outsider, não apenas em Moscou, onde isso é natural, mas também na sua terra. ${ }^{55}$

Outro aspecto relevante, segundo Bolle, é a importante correspondance "entre a mentalidade das classes sociais e a fisionomia das grandes cidades" ${ }^{56}$, 0 que mostra a construção de sentidos empreendida pelo autor ao descrever os processos políticos juntamente com a moral proletária dominante em Moscou. Benjamin realizou uma verdadeira viagem de formação (Bildungsreise), trazendo a

vantagem de poder projetar seus próprios pensamentos em algo como um campo de forças preestabelecido. A legitimidade de se permanecer fora do Partido é determinada, em última análise, pela questão de se é possível posicionar-se do lado de fora com alguma vantagem tangível e concreta, sem passar para o lado da burguesia ou prejudicar o próprio trabalho. Será possível atribuir uma justificativa concreta para meus trabalhos futuros, especialmente os científicos, com seus fundamentos formais e metafísicos? O que haveria de "revolucionário" em sua forma, se é que realmente existe algo nela de revolucionário?" In: BENJAMIN, 1989, p. 88-89.

${ }^{54}$ BENJAMIN, 1989, p. 86.

${ }^{55}$ BOLLE, 2000, p. 192.

${ }^{56}$ BOLLE, 2000, p. 180.

Priscilla Stuart da Silva - Graduada em Filosofia pela UFSC, Mestre em Educação, também pela UFSC e Doutoranda em Educação (UFSC), Brasileira, residente em Florianópolis - SC, 
experiência de uma cidade marcada por um regime proletário, uma relação fisionômica intensa com a metrópole, principalmente pelo seu aspecto de formação e pelas "marcas que a experiência soviética deixou" - pensamos aqui — em seu corpo, por meio da apreensão pelos sentidos. Ou ainda, uma busca de autoformação, uma "tentativa de encontrar-se a si mesmo" 57 . O filósofo dava uma importância grande ao Diário, segundo podemos depreender das notícias de sua dedicação à obra logo após a viagem a Moscou, na volta a Berlim, segundo relata Seligmann-Silva, ao comentar sobre outros detalhes desse texto de caráter tão íntimo:

\begin{abstract}
O texto guarda várias marcas que atestam seu hic et nuc. Uma das mais patentes é o próprio título. Na folha do manuscrito, que se encontra no arquivo Walter Benjamin, o título está rasurado, ainda que com esforço se possa ler Moskauer Tagebuch, e foi substituído por outro: Spanische Reise (Viagem espanhola). O editor dos diários, Gary Smith, especula se essa mudança não teria a função de proteger o manuscrito em um eventual controle de caráter político ou, ainda, se haveria alguma alusão literária por detrás desse gesto ou se ambos os fatores influenciaram nessa decisão. A verdade é que a rasura e a substituição de título atesta algo da história do manuscrito, e o fato de Benjamin ter escolhido a Espanha e não outro país também pode levar a conjecturas. Do diário, o texto guarda também a distribuição das entradas por dias. O autor também utiliza inúmeras vezes expressões típicas da autoescrita, algumas delas, no entanto, mais próprias da autobiografia ou das memórias, como "não me lembro muito bem" (BENJAMIN, 1989, p. 42), mas que surgem aqui, como fica claro no texto, em função dos atrasos na escrita do diário. Benjamin anota a data na qual está escrevendo sobre dias anteriores, nos quais ele não tivera tempo para escrever. O mais característico da escritura de diários é o que também mais marca esse texto: sua "presentidade". Tudo se encontra em "estado de acontecer". A força desse gesto é que sustenta a estruturação do texto e que Ihe impregna com uma irrefutável intensidade. O diário permite esse passo a passo com o autor-protagonista. $\mathrm{Na}$ intimidade, sentimos as alterações no pulsar de seu coração, nossa pele se arrepia com a dele e as paisagens descritas como que penetram pelas nossas retinas. A força do ato testemunhal do diário, Benjamin a explora com fins tanto pessoais, como literários - a até de sedução: de seus prováveis leitores, mas também de sua leitora de primeira hora que foi Asja Lacis. ${ }^{58}$
\end{abstract}

A aproximação que fazemos entre os dois ensaios que elegemos para análise nesse artigo se refere à maneira de "olhar" e apreender a cidade em muitos momentos: Benjamin procurara descrever coisas que poderiam ser consideradas insignificantes para um viajante comum. Quando pensamos no que havia para se

\footnotetext{
${ }^{57}$ Willi Bolle ressalta também que Walter Benjamin fora um dos primeiros escritores alemães a visitar a Rússia nesse período. O que antes se fazia na Itália (a viagem de formação - Bildungreise), deslocara-se para a Rússia (BOLLE, 2000, p. 180).

${ }^{58}$ SELLIGMANN-SILVA, 2012, p. 167-168.
}

Priscilla Stuart da Silva - Graduada em Filosofia pela UFSC, Mestre em Educação, também pela UFSC e Doutoranda em Educação (UFSC), Brasileira, residente em Florianópolis - SC, 
conhecer numa grande cidade como Moscou, suas descrições são muitas vezes idiossincráticas e sensoriais. Quiçá como uma criança - como a de Infância berlinense - ele busca um sentido diferente para os objetos e monumentos, a saber, espontaneidade, inspiração mágica para olhar e tocar, além de - certamente - sua fascinação por tudo que diz respeito a esse universo: brinquedos, livros, temáticas da infância em geral. Em suma, um universo que diz respeito a um colecionador, como seu interesse por caixinhas: "essa paixão origina-se da forte impressão que uma dessas caixas sempre me causou [...] o que me permite avaliar a impressão inesquecível que essas imagens sobre fundo preto de laca devem causar nas crianças", ou ainda por histórias suscitadas pelos quadros de um museu: "consegui andar por esse museu como nunca antes conseguira por uma exposição desconhecida, totalmente descontraído e entregue a um desejo de contemplação infantil das histórias que os quadros contavam"59.

Em Infância berlinense também temos o mesmo Benjamin adulto analisando uma cidade pertencente às suas memórias: ainda assim é o berlinense já crescido mostrando uma Berlim projetada por seus desejos e aflições da vida presente e não da cidade do passado por volta de 1900. Este texto também é sobre uma cidade, de acordo com as palavras do próprio Walter: "Procurei [...] apoderar-me das imagens nas quais se evidencia a experiência da grande cidade por uma criança da classe burguesa". Ou ainda: "[...] as imagens da minha infância na grande cidade talvez estejam predestinadas, no seu núcleo mais íntimo, a antecipar experiências históricas posteriores"60.

Duas categorias importantes para se pensar tanto o Diário quanto a Infância são o tempo e o espaço ${ }^{61}$. O tempo parece assemelhar-se a um relâmpago que traz a imagem do passado atualizada no presente: a imagem tanto de Berlim quanto de

\footnotetext{
${ }^{59}$ BENJAMIN, 1989, p. 93-94.

${ }^{60}$ BENJAMIN, 2004, p. 73-74.

${ }^{61}$ Em Benjamin, esta separação parece fazer sentido quando tensionada junto às categorias de forma e conteúdo; mesmo assim, sabemos da dificuldade de pensá-las separadamente: "no presente contexto, como em muitos outros, o espaço é necessariamente o correlativo do tempo. O caso individual e particular logicamente é definido com relação a duas coordenadas: espaço e tempo. Como Coleridge assinalou, psicologicamente nossa ideia de tempo está 'sempre misturada com a ideia de espaço'. Na verdade para muitos propósitos as duas dimensões são inseparáveis, como sugere o fato de as palavras 'presente' e 'minuto' poderem referir-se a qualquer dimensão; e a introspecção mostra que não conseguimos facilmente visualizar um momento particular da existência sem situá-lo também em seu contexto espacial". In: WATT, lan. O realismo e a forma do romance. In: A ascensão do romance. São Paulo: Companhia das Letras, 2010, p. 9-36.
} 
Moscou. A cidade revela os percursos que a memória de Benjamin realiza, sobretudo quando mostra o caráter da infância numa sociedade burguesa ao descrever sua própria trajetória na "idade da inocência" e quando revela, em um diário íntimo, a consolidação de um regime comunista em uma metrópole ocidental. Nesse sentido, poderíamos nos perguntar: "onde estaria o limite entre a subjetividade e a coisa pública?"62. Somente pelos sentidos conseguimos captar o tempo "fora do tempo" e senti-lo reviver novamente no presente, pois, sem isso, teríamos somente a imaginação de algo ausente, sem senti-lo. O tempo é readaptado em Benjamin. Sua alusão ao espaço é maior. Para ele, o tempo é uma instância profana ou sagrada (profanada pelo haxixe ou sagrada pela religião judaica). Sua categoria de tempo na infância é relativa ao espaço da experiência da reminiscência da memória obtida. Mais ainda: poderíamos dizer que espaço ${ }^{63} \mathrm{e}$ tempo se confundem no caleidoscópio da memória quando Benjamin reconstrói, por exemplo, as varandas da sua infância:

\begin{abstract}
As varandas mudaram menos desde a minha infância do que as outras divisões. Mas não é só por isso que as sinto mais próximas. É antes pelo consolo que a sua inabitabilidade traz a quem, por assim dizer, já não consegue viver em lugar nenhum. Nelas, a habitação do berlinense encontra a sua fronteira. Berlim - o próprio deus da cidade - começa aí. Está aí de forma tão presente que nada que seja transitório se pode afirmar a seu lado. Sob a sua proteção, o lugar e o tempo encontram-se a si mesmos, e um ao outro. Ambos se deitam aí a seus pés. Mas a criança que um dia se aliou a eles instala-se, confundindo-se com o seu grupo, na sua varanda como num mausoléu que há muito lhe estava destinado. ${ }^{64}$
\end{abstract}

Benjamin parece querer situar a categoria de tempo fora do decurso cronológico, numa instância, num limiar ou fronteira entre a memória e o presente, num lugar, a rigor, fora do tempo, num espaço em que Proust chamara de "tempo puro" ou "lembrança ausente de sensação". De acordo com o francês, a lembrança que não passa pelos sentidos é como - e simplesmente - a memória de um ausente. Não há "abalo" dos sentidos. Diferente é a memória acionada pelas sensações corpóreas:

Muitas vezes, no decurso da existência, a realidade me decepcionara porque, ao vislumbrá-la, minha imaginação, meu único órgão para sentir a

\footnotetext{
62 BOLLE, 2000, p. 193.

${ }^{63}$ Entendemos lugar e espaço como sinônimos aqui.

${ }^{64}$ BENJAMIN, 2004, p. 76.
}

Priscilla Stuart da Silva - Graduada em Filosofia pela UFSC, Mestre em Educação, também pela UFSC e Doutoranda em Educação (UFSC), Brasileira, residente em Florianópolis - SC, 
beleza, não se lhe podia aplicar, devido à lei inevitável em virtude da qual só é possível imaginar-se o ausente. [...] Onde o abalo efetivo dos sentidos, pelo som, pelo contato, acrescentara aos sonhos da fantasia aquilo de que são habitualmente desprovidos, a idéia da existência, e graças a esse subterfúgio, me fora dado obter, isolar, imobilizar o que nunca antes aprendera: um pouco de tempo em estado puro. ${ }^{65}$

Contudo, o espaço parece ser a categoria mais importante para Benjamin. Suas alusões são, na maioria das vezes, a panoramas, monumentos, colunas, parques, imagens que desenham um mosaico, caleidoscópios, esconderijos, brincadeiras de esconde-esconde, caixas, armários, museus, teatros: lugares associados a costumes, brincadeiras, modos de vida urbanos, burgueses, proletários.

Vinculadas às categorias de espaço e tempo se somam outras - de certa maneira reconfiguradas por esse padrão - como as de forma e conteúdo, na medida em que essas dualidades se coadunam numa perspectiva de dispersão e suspensão, formando algo único. Contudo, diante de uma história do pensamento sustentada por dualidades desde Platão, forçosamente identificamos o filósofo comprometido com a forma em/de seus escritos. De alguma maneira, a própria possibilidade de pensarmos uma educação do corpo em Benjamin parte da ideia de forma.

Pensando agora no espaço específico da cidade como lugar de educação dos sentidos, percebemos que ela obedece a conceitos bem demarcados "pelos discursos urbanísticos" definidos na idade moderna. É comum o conceito de cidade resguardar três momentos que a constituem, segundo a definição de Certeau: ${ }^{66}$ o de espaço próprio, o de não-tempo sincrônico e o do sujeito universal espalhado no anonimato da multidão ${ }^{67}$.

Poderíamos pensar que o não-tempo sincrônico é a categoria da "agoridade" 68 em Benjamin, aquilo que ele chamara de Jetztzeit (literalmente, tempode-agora), e o sujeito universal seria a própria multidão como personagem da cidade moderna.

\footnotetext{
${ }^{65}$ PROUST, 2009, p. 153

${ }^{66}$ As categorias utilizadas por Certeau permitem uma aproximação muito relevante com os conceitos benjaminianos aplicados à cidade moderna.

${ }^{67}$ CERTEAU, Michel de. A invenção do cotidiano. Petrópolis: Vozes, 1998, p. 172-173.

${ }^{68}$ Este neologismo foi cunhado por Haroldo de Campos para melhor adaptar o conceito de Jetztzeit, de Benjamin. In: MATOS, Olgária. Os arcanos do inteiramente outro: a escola de Frankfurt. São Paulo: Brasiliense, 1989.
} 
Destarte, o espaço da cidade, em Benjamin, se constitui, mais do que o tempo, como elemento de formação. Concordamos também com Certeau quando afirma que "o ato de caminhar parece, portanto, encontrar uma primeira definição como espaço de enunciação"69. Ampliando essa ideia, pensamos que em Benjamin a escrita promove esse lugar de enunciação, de espaço de construção do sujeito.

Os dois ensaios de Benjamin permitem pensar, simultaneamente, que 0 contato do corpo com a forma da escrita na reconstrução da memória reduz a distância (no espaço e no tempo) entre o pensamento e a escrita: promove, sobremaneira, a materialidade do pensamento na possibilidade do sentido tátil reproduzir pelas mãos as próprias ideias. A primeira estendendo-se até a última, numa imagem única e dialética.

Importante destacar que 0 ato de escrita individual na forma de um diário pessoal ou como uma narrativa das memórias, em Benjamin, demarca uma época histórica de florescência do individualismo e de perda da memória coletiva, indicando, acima de tudo, uma mudança no modo como o sujeito da experiência se relaciona com os objetos. No aforismo "Telefone"70, percebemos a mudança na

${ }^{69}$ CERTEAU, 1998, p. 177.
${ }^{70}$ Em O caminho de Guermantes, Proust descreve o surgimento do telefone em suas memórias. Este relato é importante como descrição histórico-sociológica do surgimento do aparelho como também sua relação com o corpo e com a memória coletiva: "O telefone, naquela época, ainda não era de uso tão corrente como hoje. E, no entanto, o hábito leva tão pouco tempo para despojar de seu mistério as forças sagradas com que estamos em contato que, não tendo obtido imediatamente a minha ligação, o único pensamento que tive foi que aquilo era muito demorado, muito incômodo, e quase tive a intenção de fazer uma queixa. Como nós todos agora, eu não achava suficientemente rápida, nas suas bruscas mutações, a admirável magia pela qual bastam alguns instantes para que surja perto de nós, invisível mas presente, o ser a quem queríamos falar e que, permanecendo à sua mesa, na cidade onde mora (no caso de minha avó era Paris), sob um céu diferente do nosso, por um tempo que não é forçosamente o mesmo, no meio de circunstâncias e preocupações que ignoramos e que esse ser nos vai comunicar, se encontra de súbito transportado a centenas de léguas (ele e toda a ambiência em que permanece mergulhado), junto de nosso ouvido, no momento em que nosso capricho o ordenou. E somos como a personagem do conto a quem uma fada, ante o desejo que ele exprime, faz aparecer num clarão sobrenatural a sua avó ou a sua noiva, a folhear um livro, a chorar, a colher flores, bem perto do espectador e no entanto muito longe, no próprio lugar onde realmente se encontram. Para que esse milagre se realize, só temos de aproximar os lábios da prancheta mágica e chamar - algumas vezes um pouco longamente, admito-o - as virgens vigilantes cuja voz ouvimos cada dia sem jamais Ihes conhecer o rosto, e que são nossos anjos da guarda nas trevas vertiginosas a que vigiam ciumentamente as portas; as todo poderosas por cuja intercessão os ausentes surgem ao nosso lado, sem que seja permitido vê-los: as Danaides do invisível que sem cessar esvaziam, enchem, se transmitem as urnas dos sons; as irônicas Fúrias que, no momento em que murmuramos uma confidência a uma amiga, na esperança de que ninguém nos escuta, gritam-nos cruelmente: "Estou ouvindo"; as servas sempre irritadas do Mistério, as impertinentes sacerdotisas do Invisível, as Senhoritas do Telefone! / E, logo que o nosso chamado retiniu, na noite cheia de aparições para a qual só os

Priscilla Stuart da Silva - Graduada em Filosofia pela UFSC, Mestre em Educação, também pela UFSC e Doutoranda em Educação (UFSC), Brasileira, residente em Florianópolis - SC, 
relação com o próprio corpo, na adaptação do tom de voz, dos comportamentos e costumes para esta nova maneira de interagir, a distância, com outras pessoas, e indica, de certa forma, aquilo que será a solidão moderna:

[...] O aparelho, qual herói lendário isolado no desfiladeiro da montanha, deixando para trás o corredor, fazia a sua entrada real nas salas aligeiradas e mais claras, habitadas por uma geração mais nova. Para esta, ele era o consolo da solidão. Para os desesperados que queriam deixar este mundo imperfeito, ele brilhava com a luz da última esperança. Partilhava a cama com os abandonados. Agora que todos esperavam pela sua chamada, a voz estridente que the viera do exílio soava mais quente e abafada. ${ }^{71}$

No mesmo aforismo, Benjamin comenta - por meio de sua escrita aforismática de poema em prosa - sobre a mão dominada pelo transe do toque do telefone e pelo escutar da voz, do outro lado da linha, na direção e realização de um comportamento recente nos costumes humanos: o da constituição de uma classe burguesa.

O domínio da categoria de espaço em Diário de Moscou é muito corrente quando percebemos a alusão às inúmeras igrejas e monumentos paroquiais da cidade. As estátuas da referida metrópole, em locais públicos, são muito imponentes, segundo Benjamin, na promoção do controle e influência do partido comunista sobre a mentalidade do povo, e têm ainda a função de alienar por meio do partidarismo e do nacionalismo extremos, promovidos pela propaganda de governo. A cultura também é usada na "formação" do povo russo:

\begin{abstract}
Existe uma loja na Kusnetzky most especializada em Lenin, onde se pode encontrá-lo em todos os tamanhos, poses e materiais. Na sala de lazer do clube, onde se ouvia naquele momento um concerto no rádio, há um quadro em relevo muito expressivo dele, mostrando-o como orador, em tamanho natural, de peito inflado. Imagens dele mais modestas encontram-se também nas cozinhas, lavanderias etc., da maioria dos institutos públicos./A Rússia está começando a tomar forma para o homem comum. Um grande filme de propaganda $A$ sexta parte do mundo ${ }^{72}$, foi anunciado. Em meio à neve das ruas, mapas da URSS, empilhados pelos vendedores ambulantes, são oferecidos ao público. ${ }^{73}$
\end{abstract}

nossos ouvidos se inclinam, um ruído leve - um ruído abstrato - o da distância supressa - e a voz do ser querido se dirige a nós. In: PROUST, 2007, p. 147-148.

${ }_{71}^{71}$ BENJAMIN, 2004, p. 79.

${ }^{72}$ A sexta parte do mundo é um filme russo notável, com uma estética primorosa. Nesta época se realizavam muitos filmes encomendados pelo próprio governo para a divulgação e consolidação do comunismo e a formação de uma nova mentalidade proletária.

${ }^{73}$ BENJAMIN, 1989, p. 63-64.

Priscilla Stuart da Silva - Graduada em Filosofia pela UFSC, Mestre em Educação, também pela UFSC e Doutoranda em Educação (UFSC), Brasileira, residente em Florianópolis - SC, 
Os apelos visuais e táteis, convertidos em cifras miméticas, politicamente manipuláveis, como nos ensinam Horkheimer e Adorno ${ }^{74}$, são inúmeros para a formação da mentalidade política do povo russo. A passagem acima revela uma tentativa de dominação pelos sentidos, evidenciada também em outras passagens do Diário de Benjamin, como as que relatam a utilização dos espaços públicos de divulgação, inclusive no que diz respeito ao domínio da técnica, tão prezado pelos russos $^{75}$; o uso das flores - a experiência cromática e auditiva - é normatizado, uma vez que as "flores-da-verdade", que faziam parte do espaço público antes da revolução, foram proibidas; o domínio visual do idioma russo, pela escassez das palavras de origem latina; a proibição de comer girassol em público. Trata-se de exemplos de dominação por meio de uma crença transmitida por uma educação dos sentidos na antiga Moscou ${ }^{76}$.

Uma educação, como aquela que Benjamin parece sugerir em seus escritos, está em conformidade com uma cultura e formação (Bildung) para e da vida prática. Talvez pudéssemos fazer uma distinção entre condição espiritual e condição material na obra de Benjamin. Grosso modo, essa existência espiritual se detém em discussões da ordem da abstração, da razão condicionada pela apuração de um espírito puro, que pensa na vida como contemplação, relativo a uma ordem guiada pelas ideias. Em Benjamin, percebemos uma preocupação da ordem prática, material, empírica, literalmente palpável, da ordem dos sentidos apurados. Suas descrições de Moscou são da ordem da vida e da cultura material da humanidade:

\begin{abstract}
Num armário embutido vi a enorme proteção de metal, dourada e inteiramente incrustada de pedras preciosas, que havia sido doada para 0 ícone de Rublev. As únicas partes dos corpos dos anjos que ficam descobertas são aquelas não vestidas: os rostos e as mãos. Tudo o mais era coberto pela camada de ouro maciço, e, quando o molde é colocado sobra a imagem, os pescoços e braços dos anjos, como que presos a pesadas correntes de metal, devem dar-lhes a aparência de criminosos chineses expiando seus crimes com argolas de ferro no pescoço. ${ }^{77}$
\end{abstract}

\footnotetext{
${ }^{74}$ Sobre a manipulação organizada dos impulsos miméticos, enquanto estratégia política, pelo regime nazista na Alemanha, conferir especialmente a seção $V$ do terceiro capítulo do livro Dialética do esclarecimento. In: HOKHEIMER, Max; ADORNO, Theodor W. Elementos do anti-semitismo: limites do esclarecimento. In: Dialética do esclarecimento: fragmentos filosóficos. Tradução de Guido Antonio de Almeida. Rio de Janeiro: Jorge Zahar Ed., 1985, p. 157-194.

${ }^{75}$ BENJAMIN, 1989, p. 69.

${ }^{76}$ BENJAMIN, 1989, p. 73.

77 BENJAMIN, 1989, p. 138.
}

Priscilla Stuart da Silva - Graduada em Filosofia pela UFSC, Mestre em Educação, também pela UFSC e Doutoranda em Educação (UFSC), Brasileira, residente em Florianópolis - SC, 
Mais do que uma distinção entre a vida espiritual e material, parece haver, sobretudo, uma tensão dialética entre essas duas dimensões humanas. Toda a condição espiritual, das ideias, da aura ${ }^{78}$ encontra-se no próprio acervo histórico humano, apresentado ou não para o indivíduo pela educação e cultura de seu povo, por seus descendentes, pela história que os antecedeu: "[...] quando já era mais crescido, a presença das coisas da alma no corpo não era mais difícil de desvendar do que a posição do fio da vida que, no pequeno tubo ${ }^{79}$, se furtava sempre no meu olhar" ${ }^{\prime \prime 0}$. O acesso à cultura material histórica da humanidade não se dá por uma educação pautada pela razão individualizada do corpo, mas pela educação e pelos modos que os sentidos apreendem o material dessa formação ${ }^{81}$.

$\mathrm{Na}$ fundamentação dessa ideia, poderíamos pensar na maneira enfática com que Benjamin faz uso da figura do colecionador em seus escritos sobre a cidade e em suas memórias da metrópole - seja Berlim ou Moscou. Em ambas as cidades, menciona características gráficas, de formas, cores, etc., das quais os objetos (a maior parte das vezes ele se refere a objetos de produção artesanal) são constituídos. O colecionador é uma figura alegórica que dá representatividade e materialidade para objetos que nem sempre são possuidores de valor pecuniário, e, ao fazer isso, funda um "sistema histórico novo" 82 .

${ }^{78}$ Cf. "O que é propriamente aura? Um estranho tecido fino de espaço e tempo: aparição única de uma distância, por mais próxima que esteja. Em uma tarde de verão, repousando, seguir os contornos de uma cordilheira no horizonte ou um ramo, que lança sua sombra sobre aquele que descansa - isso significa respirar a aura dessas montanhas, desse ramo". In: BENJAMIN, 2012, p. 27-29.

79 "Tubo" é o termômetro para medir a febre de Benjamin criança.

${ }^{80}$ Cf. BENJAMIN, 2004, p 94.

${ }^{81} \mathrm{O}$ pensamento de Benjamin, com seu caráter decididamente material, parece remeter a uma filosofia da vida fática onde o critério para se pensar a vida é a própria vida e não algo transcendente a ela. A transcendentalidade da vida funda-se, paradoxalmente, na própria vida, seja por meio do êxtase religioso visionário ou pelo uso de substâncias como o haxixe - que fundam uma instância sagrada na cidade.

${ }^{82}$ Cf. "É decisivo na arte de colecionar que o objeto seja desligado de todas as suas funções primitivas, a fim de travar a relação mais íntima que se pode imaginar com aquilo que lhe é semelhante. Esta relação é diametralmente oposta à utilidade e situa-se sob a categoria singular da 'completude' <?> É uma grandiosa tentativa de superar o caráter totalmente irracional de sua mera existência através da integração de um sistema histórico novo, criado especialmente para este fim: a coleção. E para o verdadeiro colecionador, cada uma das coisas torna-se neste sistema uma enciclopédia de toda a ciência da época, da paisagem, da indústria, do proprietário do qual provém. O mais profundo encantamento do colecionador consiste em inscrever a coisa particular em um círculo mágico no qual ela se imobiliza, enquanto a percorrer em último estremecimento (o estremecimento de ser adquirida)". In: BENJAMIN, 2009, H 1ª, 2.

Priscilla Stuart da Silva - Graduada em Filosofia pela UFSC, Mestre em Educação, também pela UFSC e Doutoranda em Educação (UFSC), Brasileira, residente em Florianópolis - SC, 
A cidade é o lugar de encontro com o novo, onde os produtos culturais adquirem um valor de mercadoria. Será que a figura do colecionador não seria uma tentativa de "salvar" os produtos desses (ab)usos tão amedrontadores que colocam em risco nossa capacidade estética (aisthésis), de sermos sensivelmente receptivos às obras? Uma coleção de brinquedos (tão cara a Benjamin) não recupera a dimensão do sagrado tão profanado dos usos/descartes num jogo de brincadeira infantil?

Benjamin visita Moscou como colecionador, não como turista, como dissemos anteriormente. Ele observa cada ornamento, objeto, monumento, pela ordem da "sacralidade observadora", um ritual daquele que olha e é olhado igualmente, em que o objeto é receptivo num jogo mágico; ele se abre numa receptividade que funda horizontes no espaço profano da cidade. Espaço talvez sem conteúdo para "alimentar" a narração, mas aberto aos encontros das dispersões, ao maleável e movediço de um lugar que não acumula histórias, portanto, é um lugar de passagens, limiares, pontes; não é um espaço de permanência, mas de provisoriedade.

Por outro lado, podemos compreender e refletirmos Diário de Moscou como uma narrativa sobre a capital russa na mesma medida em que Infância berlinense seria uma narrativa sobre a cidade natal do autor. Haveria aqui uma tentativa de reconstruir uma experiência de duração, entendendo duração como a incorporação simultânea de memória e narrativa perdidas como tradição pelos lapsos e crises da modernidade? 


\section{REFERÊNCIAS}

AGAMBEN, Giorgio. Profanações. Tradução Selvino J. Assmann. São Paulo: Boitempo, 2007.

- Infância e história: destruição da experiência e origem da história. Tradução Henrique Burigo. Belo Horizonte: Editora UFMG, 2008.

ADORNO, Theodor. Educação e Emancipação. Rio de Janeiro: Paz e Terra, 2010.

BENJAMIN, W. Diário de Moscou. Tradução de Hildegard Herbold. São Paulo: Companhia das Letras, 1989.

Assírio e Alvim, 2004.

. Imagens de Pensamento. Tradução de João Barrento. Lisboa:

. Obras escolhidas. Magia e Técnica, Arte e Política. Tradução de Sergio Paulo Rouanet. São Paulo: Brasiliense, 2009.

. Obras escolhidas III. Charles Baudelaire: um lírico no auge do capitalismo. São Paulo: Brasiliense, 2010.

Sobre o haxixe e outras drogas. Tradução de João Barrento.

Lisboa: Assírio \& Alvim, 2010.

BOLLE, Willi. Fisiognomia da metrópole moderna: representação da história em Walter Benjamin. São Paulo: EDUSP, 2000.

BUCK-MORSS, Susan. Dialética do olhar: Walter Benjamin e o projeto das passagens. Tradução de Ana Luiza Andrade. Belo Horizonte: Editora UFMG, 2002.

CERTEAU, Michel de. A invenção do cotidiano. Petrópolis: Vozes, 1998.

GAGNEBIN, Jeanne-Marie. História e Narração em Walter Benjamin. São Paulo: Perspectiva, 2009.

JAY, Martin. Cantos de experiência: variaciones modernas sobre un tema universal. Buenos Aires: Paidós, 2009.

MURICY, Katia. Alegorias da dialética: imagem e pensamento em Walter Benjamin. Rio de Janeiro: Nau Editora, 2009.

PEREIRA. Carlos C. F. A barbárie segundo Walter Benjamin e suas articulações com a educação. Campinas: UNICAMP, 2012. (Dissertação).

PROUST, Marcel. O caminho de Guermantes. Tradução de Mario Quintana. São Paulo: Globo, 2007. 
SELLIGMANN-SILVA, Márcio. "'O esplendor das coisas': O diário como memória do presente na Moscou de Walter Benjamin", "Escritas da violência. Vol I. O testemunho", 05/2012, ed. 1, 7Letras, Vol. 1, pp. 21, pp.263-283, 2012.

SENNETT, Richard. Carne e pedra: o corpo e a cidade na civilização ocidental. Tradução de Marcos Aarão Reis. Rio de Janeiro: Record, 2008.

WATT, lan. A ascensão do romance. São Paulo: Companhia das Letras, 2009.

WEIGEL, Sigrid. Cuerpo, Imagen y Espacio em Walter Benjamin: uma relectura. Buenos Aires: Paidós, 1999. 